\title{
Optimization of Biogas Production through Selection of Appropriate Inoculum-to-Substrate ((I/S) Ratio
}

\author{
H. I. Owamah* \\ Department of Civil Engineering, Delta State University, PMB 1, Abraka, Oleh Campus, Delta State, Nigeria.
}

\begin{abstract}
The impact of Inoculum-to-Substrate (I/S) ratio on the optimization of biogas yield from the co-digestion of FW and $\mathrm{MH}$ was investigated in five anaerobic reactors B-1 to B-5 at $37 \pm 1^{\circ} \mathrm{C}$. Cumulative biogas yield of digester B-3 $(28.92 \mathrm{~L} / \mathrm{gVS})$ with the I/S ratio 1 was higher than that of the other digesters. Simulation study through adoption of Gompertz model (modified) showed a large reduction in latency $(\lambda)$ by $59.7 \%$ with increase in I/S ratio from 0.25 to 1 , which indicates that the time taken for methanogenesis to begin was reduced by over $59 \%$. Increase in I/S ratio had positive effects on maximum specific biogas production $\left(\mathrm{R}_{\mathrm{m}}\right)$ and maximum biogas production potential (A) with reactor B-3 having the largest $\left(\mathrm{R}_{\mathrm{m}}\right)$ and $(\mathrm{A})$ values of $1.26 \mathrm{~L} / \mathrm{gVS} /$ day and $29.58 \mathrm{~L} / \mathrm{gVS}$ respectively. Lower I/S ratios of 0.25 and 0.5 were found to rather decrease biogas production. Biogas yield at I/S ratios 2 and 4 was lower than the yield at ratio 1.
\end{abstract}

KEYWORDS: Optimization, Inoculum-to-Substrate, Biogas, Gompertz modelling, Digester.

[Received January 10, 2018; Revised June 1, 2018; Accepted August 17, 2018]

Print ISSN: 0189-9546 | Online ISSN: 2437-2110

\section{INTRODUCTION}

Environmental degradation and its effects on humans is currently one of the most discussed topics in the $21^{\text {st }}$ century (Owamah et al., 2013; Asiagwu et al., 2011). The economy of the world in general and Nigeria in particular is majorly dependent on fossil fuels such as natural gas and petroleum which are non-renewable. This has led to a rapid depletion of the reserves. Moreover, exploiting, processing and combusting of these fossil fuels constitute a dangerous threat to the already weak environment (Owamah and Izinyon, 2015a). The present fast economic development and technological advancement occurring in many nations of the world implies that meeting energy demands without further deterioration of the environment may not be possible without a deliberate development and utilization of renewable energy (Zieminski et al., 2012; Roopnarain and Adeleke, 2017). Amongst the renewable energy resources, anaerobic digestion (AD) of waste organic substances (biomass) to biogas appears to be the most popular because $\mathrm{AD}$ has been noted to be among the few biotechnological processes that can generate bio-fuel, reduce environmental pollution and improve agricultural productivity through the use of its digestate as compost for organic farming (Owamah and Izinyon., 2015b; Zhang et al., 2016).

However, ensuring the viability and sustainability of industrial anaerobic digestion plants requires the optimal combination of process factors and substrates in the most costeffective manner. Co-digestion, which is the anaerobic digestion of two or more biodegradable substrates in a digester, has been used by several authors, for the optimization of biogas production potential of substrates (Haider et al., 2015; Owamah et al., 2015b). Co-digestion of different materials has

*Corresponding author: owamah.hilary@ gmail.com been reported to enhance anaerobic digestion process due to better carbon to nitrogen $(\mathrm{C} / \mathrm{N})$ balance and good synergism for supporting microbial growth and biogas production (Haider et al., 2015; Mara-Alvarez et al., 2000; Mshandete et al., 2004; Parawira et al., 2004). Because food waste contains highly degradable substances and low nitrogen content, co-digestion with complementary substrates of lower biodegradability and high nitrogen content has been found to immensely boost both biogas yield and digester stability (Owamah and Izinyon, 2015a; El-Mashad and Zhang, 2010).

Although biogas generation from plant residues has been tremendously studied and demonstrated, based on profitability and sustainability, the economics of digesters treating plant residues has been found to be unsatisfactory, because of the low biodegradability of substrates and low yield of biogas as compared to food waste and other highly biodegradable wastes (El-Mashad and Zhang, 2010). One of the methods for improving the economic favorability of digesters treating plant residues is to improve its biogas production by co-digesting them with more biodegradable wastes such as food wastes. Such co-substrates should be readily and abundantly available in the vicinity of the biogas plant (El-Mashad and Zhang, 2010). Maize husk is one of the plant residues generated in large quantities in Nigeria and many other African countries. The present improper methods of disposing these wastes (such as uncontrolled burning) could result in health hazards and also contribute to global warming. The best combination of food waste (FW) and maize husk (MH) for optimal biogas production was obtained as $75 \% \mathrm{FW}$ and $25 \% \mathrm{MH}(\mathrm{w} / \mathrm{w})$ (Owamah and Izinyon, 20 15c).

Improvement of biogas yield requires the addition of enough quantity of active inoculum needed (Boulanger et al., doi: http://dx.doi.org/10.4314/njtd.v16i1.3 
2012). This required quantity of inoculum depends on the nature of the substrate, the effect of I/S ratio etc. Some of the benefits of adding inoculum to substrates are; overcoming the problem of inhibition of reactors, and reduction of time for commencement of active methanogenesis (Moreno-Andrade and Buitron, 2003). I/S ratios, of between 1 and 4, were found to increase the methane content of biogas (Raposo et al., 2009; Parawira et al., 2004).

Having stated all these, there is presently only scanty literature information on the right I/S ratio for optimal biogas yield from the co-digestion of FW and MH. Food and maize husk wastes are hugely generated in Nigeria and many other Africa countries. This research focuses on determining the optimal I/S ratio for maximum production of biogas from $\mathrm{FW}$ and $\mathrm{MH}$. The modified Gompertz model was also used to simulate raw data for the derivation of the important kinetic parameters for predicting the performance of anaerobic reactors.

\section{MATERIALS AND METHOD}

\section{A. Material Collection and Substrate Preparation}

Collection of food waste was done on daily basis from Monday March 24th to Friday March 28th, 2014 Landmark University Restaurant. The maize husks were obtained from the farm of Landmark University. Crushing and homogenization of the substrates were done in line with the procedure in Zhang et al. (2006), and El-Mashad and Zhang (2010).

\section{B. Substrates Physico-chemical analysis}

Physico-chemical analysis of the substrates was done in triplicate in line with Standard Methods for the Examination of Water and Wastewater (APHA, 2012). Total solids (TS) and volatile solids (VS) were determined through the use of laboratory oven, model DHG-9053A. $\mathrm{NH}_{4}{ }^{+-} \mathrm{N}, \mathrm{TKN}, \mathrm{Cl}, \mathrm{P}, \mathrm{K}$, $\mathrm{S}, \mathrm{Na}, \mathrm{Ca}, \mathrm{Mg}$ were determined through the use of directreading photometer model 7100 . Initial $\mathrm{pH}$ values were measured using a $\mathrm{pH}$ meter, model PHS-3C.

\section{The Experiment for Biogas Production}

Batch anaerobic digestion was carried out to evaluate the effects of I/S ratio on biogas yield at pre-determined best combination of $\mathrm{FW}$ and $\mathrm{MH}$ (75\% $\mathrm{FW}$ and $25 \% \mathrm{MH}$ ) as established by Owamah and Izinyon, 2015c). Following the recommendation in El-Mashad and Zhang, 2010, the inoculum added to the mixed substrate was the effluent from a mesophilic anaerobic reactor digesting the same type of substrate in order to enable enough initial micro-organisms for commencement of anaerobic digestion. Computer controlled 10- liter anaerobic digesters ( 5 in No.) were used for the experiment at temperature of $37 \pm 1^{0} \mathrm{C}$. The reactors were labeled as B-1, B-2, B-3, B-4, and B-5 with respective I/S ratios of $0.25,0.5,1,2$, and 4 . The FW: MH mixture percentage and values of other determined physiochemical parameters are shown in Table 1. Similar procedure was used by Owamah and Izinyon (2015c).
Table 1. Influent substrate characteristics.

\begin{tabular}{|c|c|c|c|c|c|}
\hline Parameters & $\begin{array}{l}\text { Digester } \\
\text { B-1 }\end{array}$ & $\begin{array}{l}\text { Digester } \\
\text { B-2 }\end{array}$ & $\begin{array}{l}\text { Digester } \\
\text { B-3 }\end{array}$ & $\begin{array}{l}\text { Digester } \\
\text { B-4 }\end{array}$ & $\begin{array}{l}\text { Digester } \\
\text { B-5 }\end{array}$ \\
\hline $\begin{array}{l}{ }^{\mathrm{a}} \mathrm{FW}: \mathrm{MH} \\
(\%)(\mathrm{w} / \mathrm{w}, \\
\text { based on } \\
\text { total weight } \\
\text { (g) }\end{array}$ & $75: 25$ & $75: 25$ & $75: 25$ & $75: 25$ & $75: 25$ \\
\hline $\begin{array}{l}{ }^{\mathrm{b}} \text { Total } \\
\text { weight of } \\
\text { sample }(\mathrm{g})\end{array}$ & 30 & 30 & 30 & 30 & 30 \\
\hline $\begin{array}{l}{ }^{\mathrm{b}} \text { Weight of } \\
\text { FW (g) }\end{array}$ & 22.55 & 22.55 & 22.55 & 22.55 & 22.55 \\
\hline $\begin{array}{l}{ }^{b} \text { Weight of } \\
\text { MH (g) }\end{array}$ & 7.50 & 7.50 & 7.50 & 7.50 & 7.50 \\
\hline${ }^{b}$ VS (g/L) & 3.5 & 3.5 & 3.5 & 3.5 & 3.5 \\
\hline $\mathrm{C} / \mathrm{N}$ ratio & 23.4 & 23.4 & 23.4 & 23.4 & 23.4 \\
\hline $\mathrm{pH}$ & 7.2 & 6.9 & 6.8 & 7.1 & 5.9 \\
\hline${ }^{b} \mathrm{I} / \mathrm{S}$ & 0.25 & 0.5 & 1 & 2 & 4 \\
\hline
\end{tabular}

a based on fresh weight; ${ }^{b}$ based on volatile solid; [Source: Laboratory experiment (2014); Owamah and Izinyon (2015c)].

The digestion was allowed to run for 44 days until biogas yield became negligible. Daily volume of biogas yield was taken at 12 noon from the volumetric tank of the anaerobic digester using water displacement method. The experiments were run in duplicates and average values of daily biogas yield recorded. In order to determine the effect of the inoculum to biogas yield, two reactors containing only inoculum and water were run at similar temperature. Mean biogas yield from the inoculum was later subtracted from the main biogas yield. The TS of substrates was kept at $8 \%$ in line with the recommendation of Tchobanoglous et al. (1993). The methane content of biogas was analyzed twice in a week using a gas chromatograph (BUCK GC122, China). Plate 1 shows that sample picture of the computer controlled anaerobic reactor used for the experiment.

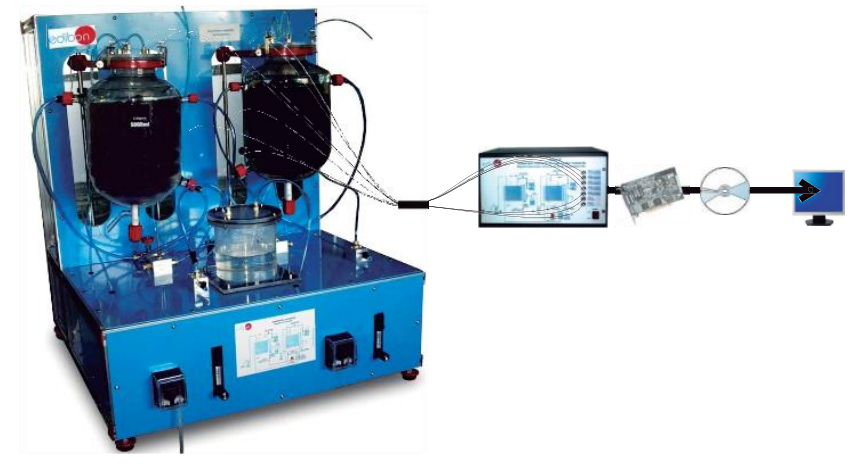

Plate 1: Reactor used for the anaerobic digestion.

\section{Modified Gompertz Model Simulation of Experimental Data}

The popular modified Gompertz model was used to estimate the maximum biogas production potential, $\mathrm{A}(\mathrm{L} / \mathrm{gVS})$, specific maximum biogas production, (L/gVS/day), and lag time (latency), (days) (Li et al., 2014, Zhu et al., 2014 etc.). The equation of the model is as shown in Eq. (1):

$$
A_{t}=A \exp \left\{-\exp \left[\frac{R_{m} \times e}{A}(\lambda-t)+1\right]\right\}
$$


where $t$ is time of biogas production (days), $A_{t}$ cumulative biogas production $(\mathrm{L} / \mathrm{gVS})$. Solver optimization function in the 2010 Microsoft Excel Package was used to obtain the values of the relevant parameters in Eq. (1) using the experimental data obtained in this study.

\section{RESULTS AND DISCUSSION}

\section{A. Effect of I/S Ratio on Digester Performance}

Table 1 shows the different combinations of food waste and maize husk and the respective I/S ratios used for the five different digesters. Comparing the values of $\mathrm{C} / \mathrm{N}$ ratio in Table $\mathrm{S} 1$ for food wastes and maize husk with the value of $\mathrm{C} / \mathrm{N}$ for the mixed substrate as obtained in Table 1, it was observed that mixing food waste with maize husk helped in achieving a better $\mathrm{C} / \mathrm{N}$ ratio of 23.4 which is within the good range of $\mathrm{C} / \mathrm{N}$ ratio prescribed for optimum biogas production (Owamah and Izinyon, 2015b). Co-digestion also helped to improve the $\mathrm{pH}$ of the final substrate (Table 1) as against the $\mathrm{pH}$ obtained individually for food waste and maize husk as shown in Table S1. Haider et al. (2015) also obtained similar improvement in substrate $\mathrm{C} / \mathrm{N}$ ratio and $\mathrm{pH}$ when they co-digested food waste and rice husk. In comparison to minimum time taken for biogas production to begin to occur as obtained when no inoculum was used (Owamah and Izinyon, 2015c), it was observed that the introduction of inoculum helped to improve the startup performances of the digesters as biogas production was observed to have begun earlier by a minimum of 4 days. Digesters B-3, B-4 and B-5 with higher I/S ratios had better startup performances than Digesters B-1 and B-2 with lower $\mathrm{I} / \mathrm{S}$ ratios. This could be attributed to increase in active methanogens which reduces the time required for the growth of the required quantity of methanogenic populations for biogas production (Boulanger et al., 2012).

From existing literature, inoculum addition to substrate improves biogas yield. This therefore makes the determination of right I/S ratio important for the efficient running of large scale anaerobic digestion plants (Raposo et al., 2009). At $\mathrm{p}<0.05$, reactor B-3 had a significant greater biogas yield than the others and cumulative biogas yield of $28.92 \mathrm{~L} / \mathrm{gVS}$. The cumulative biogas yield of B-1, B-2, B-4, and B-5 were 5.55, 6.97, 19.7 and $14.85 \mathrm{~L} / \mathrm{gVS}$ respectively. From Fig. 1, the highest biogas yield was obtained in B-3.

Table 1. Chemical properties of the prepared substrates.

\begin{tabular}{lll}
\hline Parameter & Food waste & Maize Husk \\
\hline $\mathrm{TS}(\%)$ & $66.6 \pm 0.3$ & $70.5 \pm 1.2$ \\
$\mathrm{VS}(\%)$ & $58.4 \pm 1.2$ & $28.6 \pm 0.8$ \\
$\mathrm{NH}_{4}^{+}-\mathrm{N}(\%)$ & $1.7 \pm 0.2$ & $0.8 \pm 0.2$ \\
$\mathrm{TKN}(\%)$ & $13.4 \pm 0.2$ & $10.9 \pm 0.2$ \\
$\mathrm{Cl}(\%)$ & $1.8 \pm 0.3$ & $7.2 \pm 0.5$ \\
$\mathrm{P}(\%)$ & $2.9 \pm 0.1$ & $3.7 \pm 0.1$ \\
$\mathrm{Ca}(\%)$ & $3.4 \pm 0.5$ & $9.8 \pm 0.3$ \\
$\mathrm{Mg}(\%)$ & $1.6 \pm 0.2$ & $1.9 \pm 0.1$ \\
$\mathrm{~K}(\%)$ & $3.5 \pm 0.3$ & $2.3 \pm 0.1$ \\
$\mathrm{~S}(\%)$ & $3.8 \pm 0.1$ & $4.1 \pm 0.4$ \\
$\mathrm{Na}(\%)$ & $3.4 \pm 0.3$ & $2.7 \pm 0.2$ \\
$\mathrm{Ph}$ & $4.8 \pm 0.1$ & $7.2 \pm 0.9$ \\
$\mathrm{C} / \mathrm{N}$ ratio & $13.1 \pm 0.4$ & $74.3 \pm 2.1$ \\
\hline Measurements were based on wet weight of samples.
\end{tabular}

The methane contents of digesters B-3, B-4 and B-5 were approximately the same and had an average of about 62\% (Fig. 2). Digesters B-2 and B-1 had lower mean methane content of $46.06 \%$ and $45.28 \%$ respectively. The effect of (I/S) ratio on methane content had earlier been investigated by $\mathrm{Xu}$ and $\mathrm{Li}$ (2012) on the co-digestion of expired dog food and corn stover. They observed that higher I/S ratios achieved higher daily peak biogas yield and methane content. Boulanger et al. (2012) obtained similar result in their study on the effect of I/S ratio on biogas production from municipal solid waste. Zhu et al. (2014) reported similar observation when they co-digested hay with soybean processing waste.

The mean biogas yield for digesters B-1, B-2, B-3, B-4 and B-5 were obtained as $0.25,0.32,1.31,0.87$, and 0.68 $\mathrm{L} / \mathrm{gVS}$, respectively. The result of this study in comparison with the result of similar study by the authors without inoculum

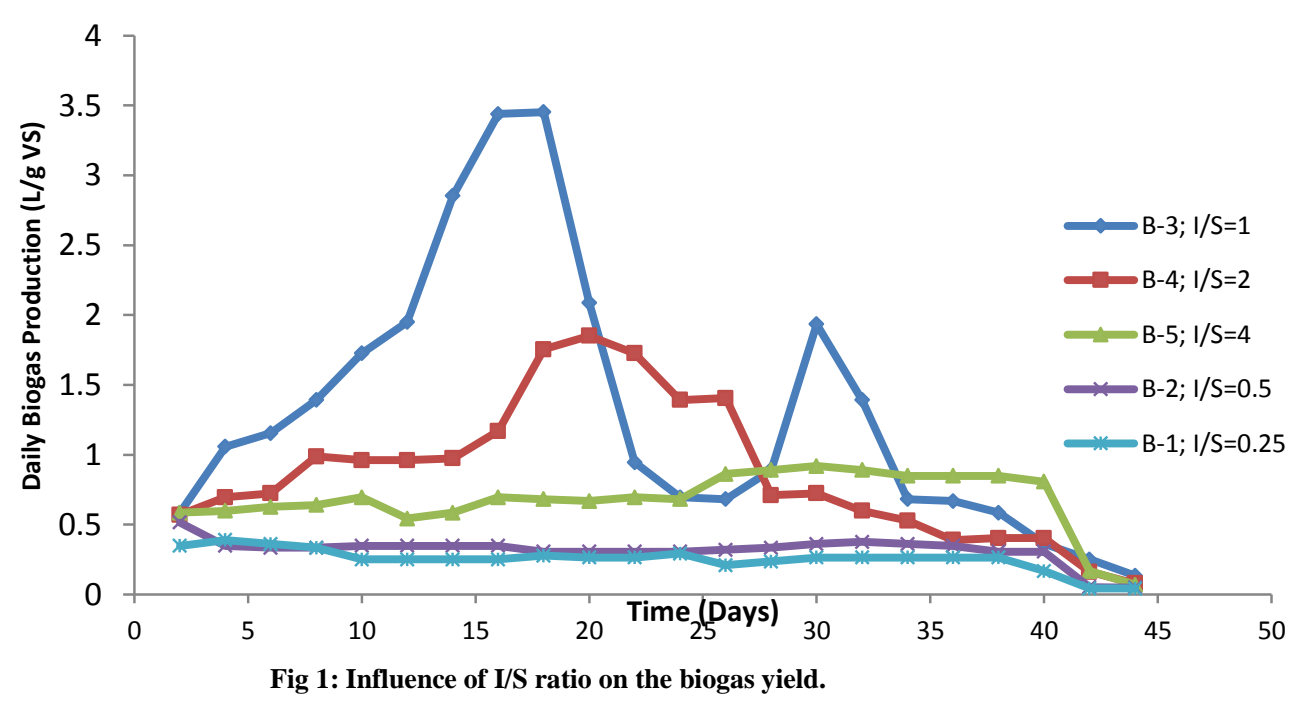




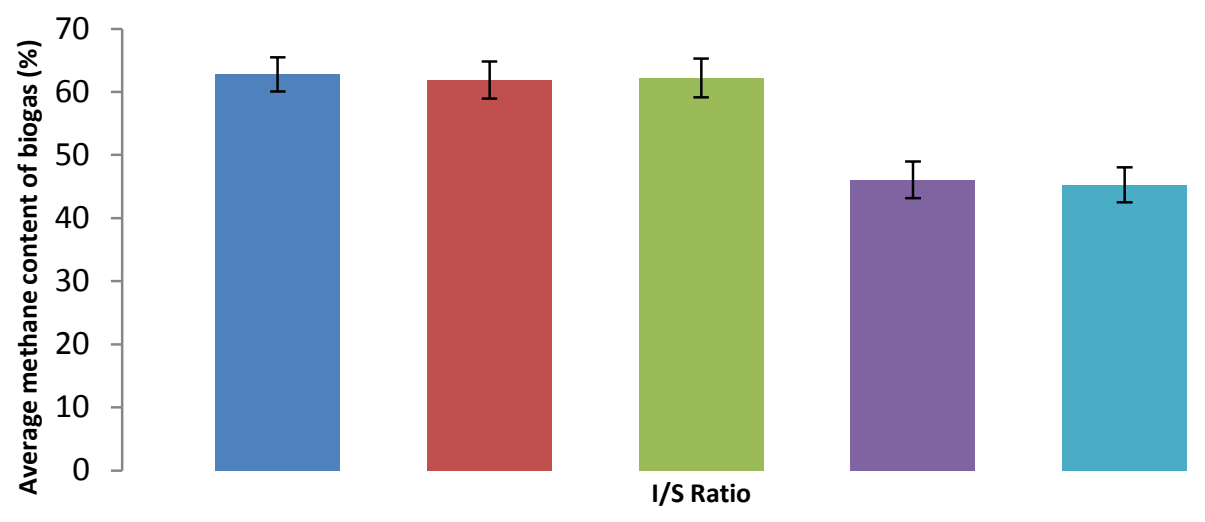

Fig. 2: Mean methane content at different I/S ratios

(Owamah and Izinyon, 2015c) shows that though addition of inoculum to substrates improves biogas yield, the ratio of the inoculum to substrate is crucial. At lower I/S ratios of 0.25 and 0.5 , the inoculum was found to rather inhibit biogas production given the very low quantity and quality of biogas produced in comparison to biogas yield when no inoculum was added to the substrate (Owamah and Izinyon, 2015c).

This inhibition could have occurred as a result of the production of intermediate products unsuitable for conversion by methanogenic bacteria to methane and insufficient amount of methanogens. However, as the I/S ratio increased, better yields were obtained with optimum performance observed when the I/S ratio was 1 . This could also be attributed to the availability of sufficient active methanogens (Boulanger et al., 2012). It must however be noted that increase in I/S ratio above 1 led to a slight decrease in biogas production. This may have resulted from changes in the nature of the surface of the substrate which may have affected the bioavailability during hydrolysis.

Addition of inoculum to substrate has been reported in literature to increase biogas yield as found in the study conducted by Parawira et al. (2004) on solid potato waste. Hashimoto (1989), and Raposo et al. (2006) study on maize and straw showed a great decrease in methane production at $\mathrm{I} / \mathrm{S}$ ratio below 0.25 expressed in $\mathrm{gVM}$ of biomass per $\mathrm{gVM}$ of substrate. Neves et al. (2004) had also reported that using granular inoculum on kitchen waste within I/S ratios of 0.2 and 4 can prevent acidification of the digestion process, which in turn improves biogas production. Boulanger et al. (2012) reported that I/S ratio of 2 was the best for optimum biogas production from municipal solid waste.

From Fig. 2, increase in I/S ratio also increased the quality of biogas. Digesters B-1 and B-2 with I/S ratios of 0.25 and 0.5 had the least methane content of about $50 \%$, while digesters B3 , B-4, and B-5 with $\mathrm{I} / \mathrm{S}$ ratios of 1,2 , and 4 had much higher methane content of above $60 \%$. The reasons adduced previously for increase in biogas yield with increase in I/S ratio may also be responsible for higher methane content values at these higher I/S ratios.

\section{B. Effect of I/S ratio on latency ( $\lambda)$}

The plots of the simulation of biogas production from digesters B-1 to B-5 using the modified Gompertz model are shown in Fig. 3.

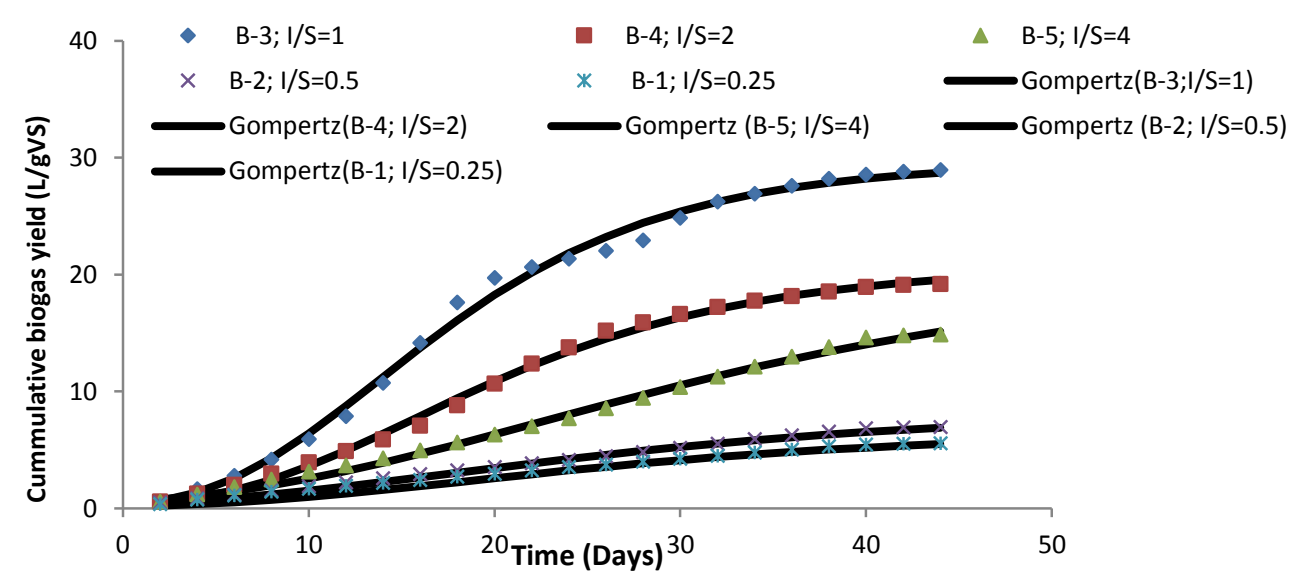

Fig. 3. Plots of modified Gompertz modeling of experimental data at various I/S ratios. 
The kinetic parameters obtained from the simulation curves of Fig. 3 were also plotted to give Fig. 4 for easy comparison of estimated kinetic parameters.

From Fig. 4, increase in I/S ratio generally decreased latency $(\lambda)$. The highest latency $(\lambda)$ of 12.4 days was obtained in digester B-1 which had I/S ratio of 0.25 . This was followed by $(\lambda)$ of 8 days in digester B-2 with $\mathrm{I} / \mathrm{S}$ ratio of 0.5 . The least latency $(\lambda)$ of 4 days was obtained when $\mathrm{I} / \mathrm{S}$ ratio was 1 (Dig. B-3). Latency $(\lambda)$ of 5.6 days and 6.7 days was obtained from digesters B-4 and B-5 with I/S ratios of 2 and 4 respectively. The large reduction in latency $(\lambda)$ of about $60 \%$ was obtained when I/S ratio was increased from 0.25 to 1 indicating that the time taken for methanogenesis to begin was reduced by about $60 \%$. The reduction in latency with increasing I/S ratio could be attributed to increase in active methanogens, which led to a reduction in the time required to grow the adequate quantity of methanogens needed for biogas production. This is usually the case in anaerobic digestion processes not inhibited by $\mathrm{pH}$ as we have in this study (Boulanger et al., 2012).

\section{Effect of I/S Ratio on Maximum Specific Biogas Production Rate $\left(R_{m}\right)$}

The modified Gompertz model simulation shows that increase in $\mathrm{I} / \mathrm{S}$ ratio has a positive effect on maximum specific biogas production $\left(\mathrm{R}_{\mathrm{m}}\right.$ ) (Fig. 4). When $\mathrm{I} / \mathrm{S}$ was $0.25, \mathrm{R}_{\mathrm{m}}$ was obtained as $0.39 \mathrm{~L} / \mathrm{gVS} /$ day. There was no noticeable change in $R_{m}$ when I/S ratio was increased to 0.5 . However, when the $\mathrm{I} / \mathrm{S}$ ratio increased to 1 as found in digester B-3, a significant rise $(69 \%)$ in $\mathrm{R}_{\mathrm{m}}$ value to $1.26 \mathrm{~L} / \mathrm{gV}$ s/day was obtained. For $\mathrm{I} / \mathrm{S}$ ratios of 2 and 4, there was improvement in $R_{m}$ but not as high as was obtained in digester B-3, with I/S ratio 1. Maximum specific biogas production $\left(R_{m}\right)$ values are significant parameters for consideration when designing /establishing large scale anaerobic plants as it gives information on the volume of biogas generation expected per day from a particular substrate. Furthermore, the higher the value of $R_{m}$, the faster the attainment of maximum biogas production potential of the substrate. The rate of biogas production and substrate consumption was maximal at $\mathrm{I} / \mathrm{S}$ ratio 1 . This finding is however different from the result reported in Boulanger et al. (2012) and could have been the effect of the difference in the substrate digested (municipal solid waste) as against FW and MH used in this study.

\section{Effect of I/S Ratio on Maximum Biogas Production Potential (A)}

Fig. 4 shows that I/S ratio had a positive effect on maximum biogas production potential (A). At lower I/S ratios of 0.25 and 0.5 , the estimated maximum biogas potential (A) was $5.1 \mathrm{~L} / \mathrm{gVS}$ and $6.3 \mathrm{~L} / \mathrm{gVS}$ respectively. This was followed by a significant increase in the maximum biogas production (A) obtained with I/S ratios 1 to 4 . However, the most significant improvement of $82.7 \%$ (with respect to $A$ at I/S ratio 0.25 ) was obtained at I/S ratio 1 (Fig. 4) in which the estimated value of (A) was $29.6 \mathrm{~L} / \mathrm{gVS}$. Estimated values of (A) for I/S ratio 2 and 4 were 20.8 and $17.9 \mathrm{~L} / \mathrm{gVS}$, respectively. Digesters B-1 and B-2 with high latency values $(\lambda)$, low $\left(R_{m}\right)$, and low (A) values (Fig. 4), can be classified as failed/highly inhibited digesters.

According to Hashimoto (1989), lower (I/S) ratios could inhibit methanogenesis with its attendant reduction in biogas yield as a result of the nature of surface of substrate that could reduce bioavailability and make hydrolysis the limiting process. Though (A) was expected to keep increasing with increase in the amount and activity of methanogens as I/S ratio increased, surprisingly the (A) for ratios higher than 1 was not as important as (A) at ratio 1. In line with Boulanger et al. (2012), this could mean that the quantity of active methanogens was no more kinetically limiting biogas production at I/S ratios higher than 1 . Given the technicality and complex nature of energy-economic considerations involved in the application of biogas for real life benefits, the Author hopes to investigate the economic perspective of this research in further studies.

$\lambda$ (Days) $\mathrm{A}(\mathrm{L} / \mathrm{g}$ VS) $\quad \mathrm{Rm}(\mathrm{L} / \mathrm{g} \mathrm{VS} /$ day)

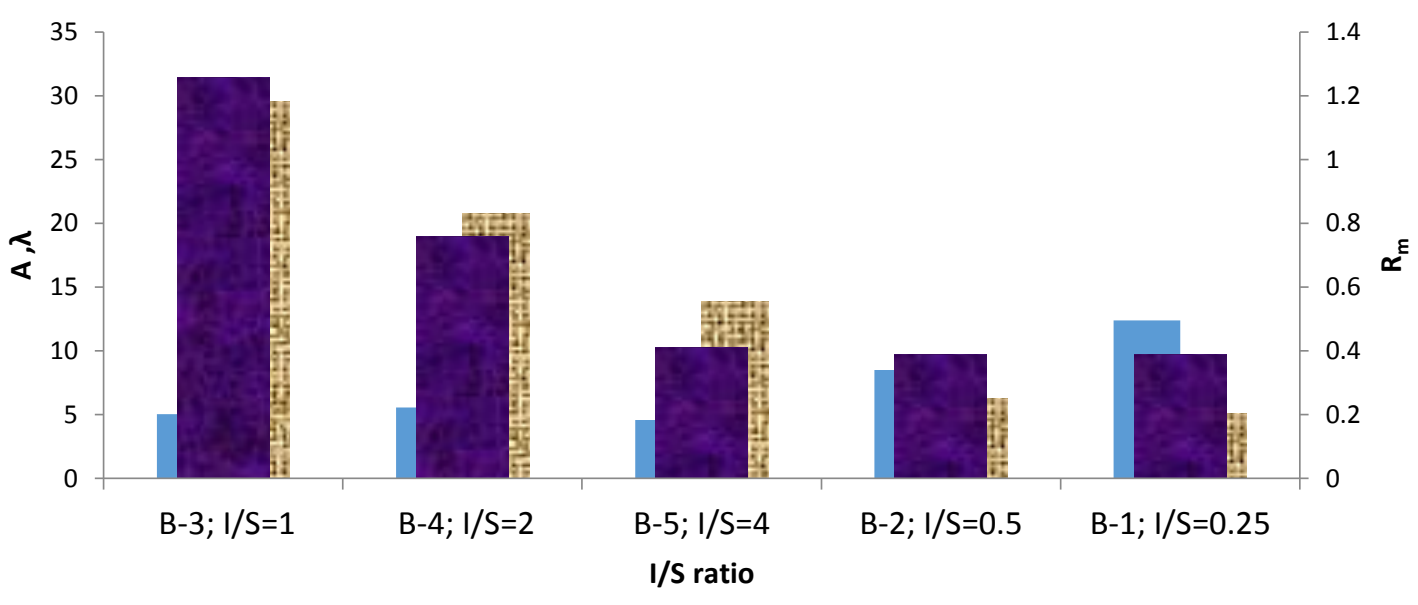

Fig. 4. Effect of I/S ratios on biogas production kinetic parameters. 
The comparison of previous results and this study (Table 2) shows that the result obtained from this study follows the trend of previous reports. Previous findings (Table 2) also substantiates the fact that appropriate selection of $\mathrm{I} / \mathrm{S}$ is imperative to the optimization of biogas yield from different substrates as also reported in previous studies shown in Table 2.

Table 2. Results of present study versus previous studies.

\section{CONCLUSION}

The study showed that I/S ratio of 1 is the best for optimization of biogas yield and methane content from the codigestion of food waste and maize husk. At lower I/S ratios, a decrease in biogas yield was obtained in the respective digesters. However, at I/S ratios above 1, only slight reduction in biogas

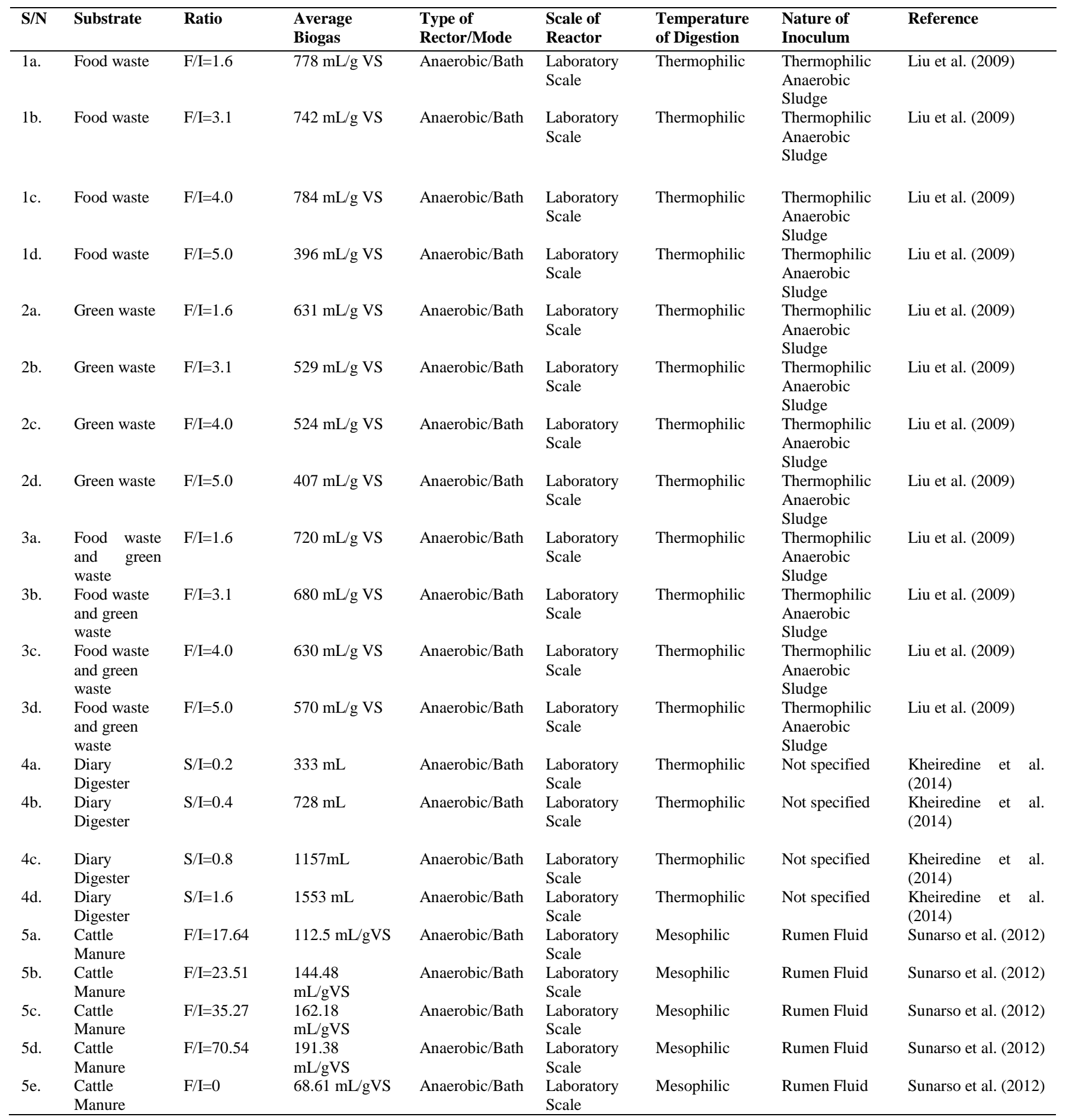


Table 2 contd. Results of present study versus previous studies.

\begin{tabular}{|c|c|c|c|c|c|c|c|c|}
\hline $\mathbf{S} / \mathbf{N}$ & Substrate & Ratio & $\begin{array}{l}\text { Average } \\
\text { Biogas }\end{array}$ & $\begin{array}{l}\text { Type of } \\
\text { Rector/Mode }\end{array}$ & $\begin{array}{l}\text { Scale of } \\
\text { Reactor }\end{array}$ & $\begin{array}{l}\text { Temperature } \\
\text { of Digestion }\end{array}$ & $\begin{array}{l}\text { Nature of } \\
\text { Inoculum }\end{array}$ & Reference \\
\hline $6 a$. & $\begin{array}{l}\text { Food waste } \\
\text { and Maize } \\
\text { Husk }\end{array}$ & $\mathrm{I} / \mathrm{S}=0.25$ & $0.25 \mathrm{~L} / \mathrm{gVS}$ & Anaerobic/Bath & $\begin{array}{l}\text { Laboratory } \\
\text { Scale }\end{array}$ & Mesophilic & $\begin{array}{l}\text { Mesophilic } \\
\text { Anaerobic } \\
\text { Sludge }\end{array}$ & Present study \\
\hline $6 b$. & $\begin{array}{l}\text { Food waste } \\
\text { and Maize } \\
\text { Husk }\end{array}$ & $\mathrm{I} / \mathrm{S}=0.5$ & $0.32 \mathrm{~L} / \mathrm{gVS}$ & Anaerobic/Bath & $\begin{array}{l}\text { Laboratory } \\
\text { Scale }\end{array}$ & Mesophilic & $\begin{array}{l}\text { Mesophilic } \\
\text { Anaerobic } \\
\text { Sludge }\end{array}$ & Present study \\
\hline $6 c$. & $\begin{array}{l}\text { Food waste } \\
\text { and Maize } \\
\text { Husk }\end{array}$ & $\mathrm{I} / \mathrm{S}=1$ & $1.31 \mathrm{~L} / \mathrm{gVS}$ & Anaerobic/Bath & $\begin{array}{l}\text { Laboratory } \\
\text { Scale }\end{array}$ & Mesophilic & $\begin{array}{l}\text { Mesophilic } \\
\text { Anaerobic } \\
\text { Sludge }\end{array}$ & Present study \\
\hline $6 \mathrm{~d}$. & $\begin{array}{l}\text { Food waste } \\
\text { and Maize } \\
\text { Husk }\end{array}$ & $\mathrm{I} / \mathrm{S}=2$ & $0.87 \mathrm{~L} / \mathrm{gVS}$ & Anaerobic/Bath & $\begin{array}{l}\text { Laboratory } \\
\text { Scale }\end{array}$ & Mesophilic & $\begin{array}{l}\text { Mesophilic } \\
\text { Anaerobic } \\
\text { Sludge }\end{array}$ & Present study \\
\hline $6 e$. & $\begin{array}{l}\text { Food waste } \\
\text { and Maize } \\
\text { Husk }\end{array}$ & $\mathrm{I} / \mathrm{S}=4$ & $0.68 \mathrm{~L} / \mathrm{gVS}$ & Anaerobic/Bath & $\begin{array}{l}\text { Laboratory } \\
\text { Scale }\end{array}$ & Mesophilic & $\begin{array}{l}\text { Mesophilic } \\
\text { Anaerobic } \\
\text { Sludge }\end{array}$ & This study \\
\hline
\end{tabular}

yield as compared with yield at I/S ratio 1 was obtained. The modified Gompertz model revealed that lower I/S ratios of 0.25 and 0.5 had longer latency of 12.4 and 8.5 days respectively. With $\mathrm{I} / \mathrm{S}$ ratio 1 , lower (better) latency of 5 days was obtained. Again, the highest $A$ and maximum $R_{m}$ were obtained at I/S ratio 1 . This study therefore recommends that for large scale industrial production of biogas using food waste and maize husk, I/S ratio of 1 should be adopted.

\section{REFERENCES}

APHA (2012). American Public Health Association: Standard Methods for Examination of Water and Waste-water. 22nd Edition, Washington DC, USA.

Asiagwu, A.K.; H. I. Owamah and V.O. Illoh (2012). Kinetic and Thermodynamic Models for the Removal of Aminophenol (Dye) from Aqueous Solutions using Groundnut (Arachis Hypogea) Shells as the Biomass. Advances in Applied Sciences Research, 3(4): 2257-2265.

Bani, K.; D.Kerroum and B. Mosaab (2014). Effect of Inoculums to Substrate Ratio on Thermophilic Anaerobic Digestion of the Dairy Wastewater. Chemical Engineering Transactions 37:865-870.

Boulanger, A.; E. Pinet; M. Bouix; T. Bouchez and A.A. Mansour (2012). Effect of Inoculum to Substrate Ratio (I/S) on Municipal Solid Waste Anaerobic Degradation Kinetics and Potential. Waste Management, 32, 22582265.

Boe, K.; J.B. Damien; S. Jean-Phillippe and A. Irini (2010). State Indicators for Monitoring the Anaerobic Digestion Process. Water Research 44:5973-5980.

El-Mashad, H.M. and Zhang, R. (2010). Biogas Production from Co-digestion of Dairy Manure and Food Waste. Bioresource Technology, 101:4021-4028.

Haider, M.R.; Y.S. Zeshan; R.N. Malik and C. Visvanathan (2015). Effect of mixing ratio of food waste and rice husk co-digestion and substrate to inoculum ratio on biogas production. Bioresource Technology 190: 451-457.
Hashimoto, A.G. (1989). Effect of Inoculum/Substrate Ratio on Methane Yield and Production Rate from Straw. Biological Wastes, 28:247-255.

Kim, M.; Y. Ahn and R.E. Speece (2002). Comparative Process Stability and Efficiency of Anaerobic Digestion; Mesophilic vs. Thermophilic. Water Research, 36 (17): 4369 4385.

Liu, G.; R. Zhang; M.H. El-Mashad and R. Dong (2009). Effect of Feed to Inoculum Ratios on Biogas Yields of Food and Green Wastes. Bioresource Technology 100:51035108.

Li, Y.; R. Zhang; Y. He; C. Zhang; X. Liu and C. Chen (2014). Anaerobic Co-digestion of Chicken Manure and Corn Stover in Batch and Continuous Stirred Tank Reactor (CSTR). Bioresource Technology, 156:342-347.

Mata- Alvarez, J.; S. Mace and P. Llabres (2000). Anaerobic Digestion of Organic Solid Waste: an Overview of Research Achievements and Perspectives. Bioresource Technology, 74(1): 3-16.

Mishandete, A.; A. Kivaisi; M. Rubindamayugi and B. Mattiasson (2004). Anaerobic batch co-digestion of sisal pulp and fish wastes. Bioresource Technology, 95(1): 19-24.

Moreno-Andrede, I. and Buitron, C. (2003). Influence of the Initial Substrate to Microorganisms Concentration Ratio on the Methanogenic Inhibition Test. Water Science and Technology 48: 17-22.

Neves, L.; R. Olivera and M.M. Alves (2004). Influence of Inoculum Activity on the Bio-methanization of a Kitchen Waste under different Waste/Inoculum Ratios. Process Biochemistry 39:2019-2024.

Owamah, H.I.; A.K. Asiagwu; S.H.O. Egboh and S. Phil-Usiayo (2013). Drinking Water Quality at Isoko North Communities of the Niger-Delta Region, Nigeria. Toxicological and Environmental Chemistry, 95(7):11161128.

Owamah, H.I. and Izinyon, O.C. (2015a). Development of simple-to-apply biogas kinetic models for the Co-digestion 
of Food Waste and Maize Husk. Bioresource Technology 194: 83-90.

Owamah, H.I. and Izinyon, O.C. (2015b). Optimal Combination of Food Waste and Maize Husk for Enhancement of Biogas Production: Experimental and Modelling Study. Environmental Technology \& Innovation 4: 311-318.

Owamah, H.I. and Izinyon, O.C. (2015c). The Effect of Organic Loading Rates (OLRs) on the Performances of Food Wastes and Maize Husks Anaerobic Co-digestion in Continuous Mode. Sustainable Energy Technology and Assessment 11: 71-76.

Parawira, W.; M. Murto; R. Zvauya and B. Mattiasson (2004). Anaerobic Batch Digestion of Solid Potato Waste Alone and in Combination with Sugar Beet Leaves. Renewable Energy, 29: 1811-1823.

Raposo, F.; C. J. Banks; I. Siegert; S. Heaven and R. Borja (2006). Influence of inoculum to substrate ratio on the biochemical methane potential of maize in batch tests. Process Biochemistry, 41:1444-1450.

Raposo, F.; R. Borja; M.A. Martin; A. Martin; M.A. de la Rubia and B. Rincon (2009). Influence of Inoculum to Substrate Ratio on the Anaerobic Digestion of Sunflower Oil Cake in Batch Mode: Process Stability and Kinetic Evaluation. Chemical Engineering Journal, 149:70-77.

Roopnarain, A. and Adeleke, R. (2017). Current Status, Hurdles and Future Prospects of Biogas Digestion Technology in Africa. Renewable and Sustainable Energy Reviews, 67: 1162-1179.
Sunarso, J.; S. Widiasa and I.N. Budiyono (2012). The Effect of Feed to Inoculums Ratio on Biogas Production Rate from Cattle Manure Using Rumen Fluid as Inoculums. Internat. J. of Waste Resources, 2(1):1-4.

Tchobanoglous, G.; H. Theisen and S. Vigil (1993). Integrated Solid Waste Management Engineering: Principles and Management Issues. Singapore, McGraw-Hill U.S.

Xu, F. and Li, Y. (2012). Solid-State Co-digestion of Expired Dog Food and Corn Stover for Methane Production. Bioresource Technology, 118:219-226.

Zhang, R.; H. M. El-Mashad; K. Hartman; F. Wang; G. Liu; C. Choate and P. Gamble (2006). Characterization of Food Waste as Feedstock for Anaerobic Digestion. Bioresource Technology, 98:929-935.

Zhang, Q.; J. Hu and D. Lee (2016). Biogas from Anaerobic Digestion Processes: Research Updates. Renewable Energy, 98:108-119.

Zhu, J.; Z. Yi; X. Fuqing and L. Yebo (2014). Solid-State Anaerobic Co-digestion of Hay and Soybean Processing Waste for Biogas Production. Bioresource Technology, 154: 240247.

Zieminski, K.; I. Romanowska and M. Kowalska (2012). Enzymatic Pretreatment of Linocellulosic Waste to improve Biogas Production. Waste Management 32: 11311137. 